\title{
Utilization of Cogen Ash for Enhancing Growth and Yield of Paddy
}

\author{
N. Hamsa ${ }^{1}$, C.A. Srinivasamurthy ${ }^{2}$, S. Bhaskar ${ }^{3}$ and L.R. Varalakshmi ${ }^{4}$ \\ ${ }^{1}$ Department of Soil Science and Agricultural Chemistry, University of Agricultural Sciences, \\ G.K.V.K, Bengaluru 560065, India \\ ${ }^{2}$ Director of Research, Central Agriculture University, Iroismba, Imphal, Manipur- 795004, India \\ ${ }^{3}$ Assistant Director General (Agronomy, Agroforestry and Climate change) \\ KAB II, ICAR-110001, India \\ ${ }^{4}$ Principal Scientist, Division of Soil Science and Agricultural Chemistry, \\ IIHR, Bengaluru 560089, India \\ *Corresponding author
}

\section{A B S T R A C T}

\section{Ke y w o r ds \\ Cogen ash, growth and yield of paddy, FYM, plant nutrients, harvest index, correlation.}

Article Info

Accepted: 04 April 2017 Available Online: 10 May 2017
Cogen ash, a by-product of sugar mills obtained during co-generation process to produce heat and electrical energy by burning bagasse and/or coal was used to study its effect on growth and yield of paddy. The experiment was conducted in two sites at Bharathinagar, K.M. Doddi, Mandya during kharif 2014 with 13 treatments replicated thrice using randomized complete block design. The cogen ash collected from M/s Sri Chamundeshwari Sugars Ltd. was used in the study was more of silt sized, alkaline in nature with medium EC. Cogen ash was applied at different levels along with recommended doses of fertilizers and different levels of FYM. Cogen ash contains some amount of plant nutrients ( $\mathrm{K}, \mathrm{Ca}, \mathrm{Mg}$ and micro nutrients) which can be taken up by the plants directly or indirectly for their growth and production. It was found that on application of recommended doses of fertilizers with $100 \%$ recommended doses of FYM and $15 \mathrm{t} \mathrm{ha}^{-1}$ of cogen ash significantly increased grain yield and straw yield to an extent of $46.92 \%$ and $33.54 \%$, respectively.

\section{Introduction}

Co-generation is the concept of producing two forms of energy from one fuel source. The ash produced during this process is the cogen ash. Disposal of cogen ash has become a serious problem and large quantities of this ash are regularly disposed into rivers, ponds and open spaces thereby endangering the fragile ecosystems.

It is anticipated that by 2025 A.D, India will need around $310 \mathrm{MT}$ of food grain to feed
1500 million people and the greater production in future has to come from higher productivity per unit land (Dev, 1995). Approach has to be developed to aim at high productivity and also sustain it in the long run.

Development of such technologies will simultaneously answer the issue of disposal of cogen ash and also increasing productivity of agricultural land. Along with chemical 
fertilizers, repeated application of organic manures is often recommended in order to maintain soil productivity. Traditionally, farmyard manure is the major organic source, now its availability is limited. On the other hand, the price of commercial fertilizers has been increasing year by year.

Under such situations, the locally available organic wastes like biomass ashes would be a valuable alternative to commercial fertilizers for the resource poor farmers for sustaining the productivity. Ash can be effectively used in agriculture for crops such as paddy and others, which can supply sufficient amount of plant nutrients for improving crop growth and productivity, which otherwise may create nuisance and pollute the environment and may occupy vast areas of productive land given the present mode of disposal. Hence present investigation was taken up to utilize cogen ash to enhance growth and yield parameters of paddy.

\section{Materials and Methods}

Field experiments were conducted to study the effect of cogen ash on crop growth in two sites at Bharathinagar, Maddur taluk, located in Mandya District, which falls under Southern Dry Zone of Karnataka at an altitude of 662 meters above mean sea level during the year 2014. Paddy was taken as a test crop with application of recommended dose of fertilizers 100:50:50 kg N: $\mathrm{P}_{2} \mathrm{O}_{5}: \mathrm{K}_{2} \mathrm{O} \mathrm{ha}^{-1}$ and recommended dose of FYM of $10 \mathrm{tha}^{-1}$.

Thirty-day-old rice seedlings were planted at a spacing of $15 \mathrm{~cm}$ within rows and $20 \mathrm{~cm}$ between rows. Rice variety IR 30864 was planted in both the sites. The cogen ash used in the treatments was alkaline in $\mathrm{pH}$ with medium E.C and more of silt sized particles. Experiments were conducted with 13 treatments as mentioned below and 3 replications thrice.

\section{Treatment details}

$\mathbf{T}_{\mathbf{1}}: \mathrm{RDF}+\mathrm{RD}$ of FYM
$\mathbf{T}_{\mathbf{2}}: \mathrm{RDF}+2.5 \mathrm{t} \mathrm{ha}^{-1} \mathrm{CGA}$
$\mathbf{T}_{\mathbf{3}}: \mathrm{RDF}+5.0 \mathrm{t} \mathrm{ha}^{-1} \mathrm{CGA}$
$\mathbf{T}_{\mathbf{4}}: \mathrm{RDF}+10.0 \mathrm{t} \mathrm{ha}^{-1} \mathrm{CGA}$
$\mathbf{T}_{\mathbf{5}}: \mathrm{RDF}+15 \mathrm{tha}^{-1} \mathrm{CGA}$
$\mathbf{T}_{\mathbf{6}}: \mathrm{RDF}+\mathrm{RD}$ of FYM $+2.5 \mathrm{tha}^{-1} \mathrm{CGA}$
$\mathbf{T}_{\mathbf{7}}: \mathrm{RDF}+\mathrm{RD}$ of FYM $+5.0 \mathrm{tha}^{-1} \mathrm{CGA}$
$\mathbf{T}_{\mathbf{8}}: \mathrm{RDF}+\mathrm{RD}$ of FYM $+10.0 \mathrm{tha}^{-1} \mathrm{CGA}$
$\mathbf{T}_{\mathbf{9}}: \mathrm{RDF}+\mathrm{RD}$ of FYM $+15.0 \mathrm{tha}^{-1} \mathrm{CGA}$
$\mathbf{T}_{\mathbf{1 0}}: \mathrm{RDF}+50 \%$ of RD of FYM $+2.5 \mathrm{t} \mathrm{ha}^{-1}$
CGA
$\mathbf{T}_{\mathbf{1 1}}: \mathrm{RDF}+50 \%$ of RD of FYM $+5.0 \mathrm{t} \mathrm{ha}^{-1}$
CGA
$\mathbf{T}_{\mathbf{1 2}}: \mathrm{RDF}+50 \%$ of RD of FYM $+10.0 \mathrm{t} \mathrm{ha}^{-1}$
CGA
$\mathbf{T}_{\mathbf{1 3}}: \mathrm{RDF}+50 \%$ of RD of FYM $+15.0 \mathrm{t} \mathrm{ha}^{-1}$
CGA

Note: RDF- recommended dose of fertilizers. RD- recommended dose

CGA- cogen ash.

FYM- farm yard manure

Growth observations of paddy were taken at harvest of the crop. Grain and straw yields were recorded from each site and under different treatments. Percent increase in yield by treatments over control was assessed. f \%, HI calculated as given by Donald and Humblin, 1976

$\mathrm{HI}=\frac{\text { Grain yield }}{\text { Biomass yield }}$

The analyses and interpretation of the data was done using the Fisher's method of analysis and variance technique as given by Panse and Sukhatme (1967).

\section{Results and Disussion}

\section{Plant growth parameters}

The data on plant height, number of leaves per tiller of paddy as influenced by the 
application of varied levels of cogen ash are presented in table 1. Plant height did not vary significantly in site 1 . However, highest plant height was observed in the treatment $\mathrm{T}_{9}$ which received recommended dose of NPK + RD FYM + 15 t ha ${ }^{-1}$ cogen ash. Plant height differed significantly at harvest stage of crop growth due to application of varied levels of cogen ash in site 2 (Table 2 and 3 ). The plant height was lower in the treatment $\mathrm{T}_{2}$ which received $2.5 \mathrm{t} \mathrm{ha}^{-1}$ of cogen ash and RDF. Number of leaver per tiller did not vary significantly. However highest number of tillers per hill was observed in the treatment $\mathrm{T}_{9}$ in both the sites. Growth and growth parameters were higher in the treatments with recommended dose of fertilizers and higher rates of cogen ash and the further improvement was observed in combination with $100 \%$ recommended dose of FYM, followed by $50 \%$ recommended dose of FYM. Jamil et al., (2007) found an increase in plant height and spike length of wheat which might be due to sufficient amount of available $\mathrm{P}$ and micronutrients supplied by bagasse ash. Upadhayay et al., (2001) and Stosio and Tomaszewicz (1999) also reported increase in plant height, spike length and biomass of three native species of wheat treated with bagasse ash.

\section{Grain and straw yield, Yield parameters and Harvest Index (Table 2 to 5)}

The increase in yield parameters was observed with increase in the rates of cogen ash application. However, the treatment $\mathrm{T}_{9}$ (recommended dose of fertilizers + recommended dose of FYM $+15.0 \mathrm{t} \mathrm{ha}^{-1}$ cogen ash) recorded significantly higher number of panicles hill $^{-1}$, number of grains panicle $^{-1}$ and test weight in site 1 and the same trend was observed in site 2. Higher grain and straw yield was recorded in $\mathrm{T}_{9}$ (6.67, $6.99 \mathrm{t} \mathrm{ha}^{-1}$ and 6.23, $6.38 \mathrm{t} \mathrm{ha}^{-1}$ in sites 1 and 2, respectively). The increase in grain yield with the treatment $\mathrm{T}_{9}$ over control was found to be $56.21 \%$ and $38.44 \%$ in sites 1 and 2 , respectively. Yields obtained from control plot receiving RDF and RD FYM was found to be significantly higher compared to $\mathrm{T}_{2}$ (RDF $+2.5 \mathrm{t} \mathrm{ha}^{-1}$ of cogen ash) in both the plots. $\mathrm{T}_{2}$ treatment showed negative increase in grain and straw yield over the control. Application of recommended dose of fertilizers + recommended dose of FYM + $15.0 \mathrm{t} \mathrm{ha}^{-1}$ cogen ash was found to increase $46.92 \%$ and $33.54 \%$ of grain and straw yield over the control plot that received only recommended dose of FYM and fertilizers. The mean harvest index of 0.491 was obtained for the treatment $\mathrm{T}_{9}$, which is found to be highest while, 0.466 was for control i.e. $\mathrm{T}_{1}$. Among the ash treatments in combination with varied doses of FYM, cogen ash at higher rates $\left(15.0 \mathrm{t} \mathrm{ha}^{-1}\right)$ combined with 100 $\%$ RD FYM recorded better grain and straw yield and yield parameters which was followed by $50 \%$ RD FYM with cogen ash than the ash applied without FYM. Application of RDF + RD FYM alone was found to be better than the application of lesser amount of cogen ash without FYM.

Top dressing paddy crop with urea (split application) might have been the reason for good growth and yield. Milthrape and Ivins (1966) reported that providing nitrogen timely enhances total biomass yield of crop especially cereals. The positive effect on yield and yield parameters due to combined use of cogen ash, chemical fertilizers and FYM might be due to improvement in the availability of plant nutrients and balanced supply of nutrients through organic manures and inorganic fertilizers (Das et al., 2013) that might have induced the cell division, expansion of cell wall, meristematic activity, photosynthetic efficiency, increased nutrient absorption by increased root activity thus resulting in better growth and development of crop, increased fertile panicles, number of grains per panicle and test weight and this led to increased grain and straw yield of crop. 
Table.1 Effect of varied levels of cogen ash on growth parameters of paddy at harvest

\begin{tabular}{|c|c|c|c|c|c|c|}
\hline & \multicolumn{3}{|c|}{ Plant height } & \multicolumn{3}{|c|}{$\begin{array}{c}\text { Number of leaves per } \\
\text { tiller }\end{array}$} \\
\hline Treatments & Site -1 & Site -2 & Mean & Site -1 & Site -2 & Mean \\
\hline$T_{1}$ & 73.00 & 67.53 & 70.27 & 4.20 & 4.33 & 4.27 \\
\hline $\mathbf{T}_{2}$ & 65.53 & 64.73 & 65.13 & 4.20 & 4.07 & 4.14 \\
\hline $\mathbf{T}_{3}$ & 70.53 & 65.80 & 68.17 & 4.33 & 4.27 & 4.30 \\
\hline$T_{4}$ & 70.73 & 67.27 & 69.00 & 4.40 & 4.33 & 4.37 \\
\hline$T_{5}$ & 72.07 & 69.53 & 70.80 & 4.47 & 4.53 & 4.50 \\
\hline$T_{6}$ & 71.33 & 66.93 & 69.13 & 4.40 & 4.07 & 4.24 \\
\hline $\mathbf{T}_{7}$ & 72.87 & 67.93 & 70.40 & 4.53 & 4.20 & 4.37 \\
\hline$T_{8}$ & 73.33 & 70.43 & 71.88 & 4.53 & 4.40 & 4.47 \\
\hline$T_{9}$ & 74.93 & 73.70 & 74.32 & 4.60 & 4.53 & 4.57 \\
\hline$T_{10}$ & 71.07 & 65.20 & 68.14 & 4.20 & 4.40 & 4.30 \\
\hline$T_{11}$ & 71.47 & 68.73 & 70.10 & 4.47 & 3.87 & 4.17 \\
\hline$T_{12}$ & 71.47 & 69.00 & 70.24 & 4.53 & 3.93 & 4.23 \\
\hline$T_{13}$ & 71.93 & 70.77 & 71.35 & 4.53 & 4.13 & 4.33 \\
\hline S. Em \pm & 2.15 & 1.60 & & 0.16 & 0.19 & \\
\hline C. D. at $5 \%$ & NS & 4.68 & & NS & NS & \\
\hline
\end{tabular}

Table.2 Effect of varied levels of cogen ash on yield parameters of paddy at harvest

\begin{tabular}{|c|c|c|c|c|c|c|c|c|c|}
\hline \multirow[b]{2}{*}{ Treatments } & \multicolumn{3}{|c|}{ Number of panicles hill ${ }^{-1}$} & \multicolumn{3}{|c|}{$\begin{array}{c}\text { Number of grains } \\
\text { panicle }^{-1}\end{array}$} & \multicolumn{3}{|c|}{ Test weight (g) } \\
\hline & Site-1 & Site -2 & Mean & Site-1 & Site -2 & Mean & Site-1 & Site -2 & Mean \\
\hline$T_{1}$ & 16.87 & 17.80 & 17.34 & 177.38 & 227.81 & 202.60 & 29.17 & 23.80 & 26.49 \\
\hline $\mathbf{T}_{2}$ & 14.20 & 12.87 & 13.54 & 222.90 & 265.45 & 244.18 & 20.57 & 22.18 & 21.38 \\
\hline$T_{3}$ & 16.00 & 16.00 & 16.00 & 227.59 & 265.87 & 246.73 & 24.40 & 22.36 & 23.38 \\
\hline $\mathbf{T}_{4}$ & 16.23 & 17.33 & 16.78 & 245.03 & 269.27 & 257.15 & 25.40 & 23.80 & 24.60 \\
\hline $\mathbf{T}_{5}$ & 16.30 & 17.53 & 16.92 & 246.99 & 276.72 & 261.86 & 26.83 & 24.71 & 25.77 \\
\hline$T_{6}$ & 14.33 & 16.33 & 15.33 & 251.68 & 265.81 & 258.75 & 24.63 & 23.94 & 24.29 \\
\hline $\mathbf{T}_{7}$ & 15.53 & 17.20 & 16.37 & 269.13 & 276.37 & 272.75 & 26.30 & 25.06 & 25.68 \\
\hline $\mathbf{T}_{8}$ & 17.20 & 18.07 & 17.64 & 280.89 & 283.07 & 281.98 & 29.87 & 25.92 & 27.90 \\
\hline $\mathbf{T}_{9}$ & 19.00 & 18.53 & 18.77 & 317.70 & 308.94 & 313.32 & 29.90 & 29.69 & 29.80 \\
\hline $\mathbf{T}_{10}$ & 15.07 & 15.80 & 15.44 & 232.35 & 224.00 & 228.18 & 22.50 & 22.31 & 22.41 \\
\hline$T_{11}$ & 17.13 & 16.93 & 17.03 & 238.00 & 244.54 & 241.27 & 25.70 & 24.18 & 24.94 \\
\hline$T_{12}$ & 17.43 & 17.80 & 17.62 & 258.84 & 258.97 & 258.91 & 29.30 & 24.79 & 27.05 \\
\hline$T_{13}$ & 18.53 & & 18.43 & 313.86 & 268.52 & 291.19 & 29.47 & 25.19 & 27.33 \\
\hline S. E & 0.8 & 0.80 & & 12.96 & 14.04 & & $\mathbf{0 . 0 7 8}$ & 0.37 & \\
\hline C. D. at $5 \%$ & 2.49 & 2.34 & & 37.84 & 41.14 & & 0.23 & 1.07 & \\
\hline
\end{tabular}


Table.3 Effect of varied levels of cogen ash on grain yield of paddy and Percentage increase in yield over control

\begin{tabular}{|c|c|c|c|c|c|c|}
\hline & \multicolumn{3}{|c|}{ Grain yield $\left(t h^{-1}\right)$} & \multicolumn{3}{|c|}{$\begin{array}{c}\text { Percent Increase in yield } \\
\text { over control }\end{array}$} \\
\hline Treatments & Site-1 & Site -2 & Mean & Site-1 & Site -2 & Mean \\
\hline $\mathbf{T}_{1}$ & 4.27 & 4.50 & 4.39 & - & - & - \\
\hline $\mathbf{T}_{2}$ & 3.93 & 4.18 & 4.06 & -7.96 & -7.11 & -7.52 \\
\hline $\mathbf{T}_{3}$ & 4.44 & 4.94 & 4.69 & 3.98 & 9.78 & 6.83 \\
\hline $\mathbf{T}_{4}$ & 5.04 & 5.19 & 5.12 & 18.03 & 15.33 & 16.63 \\
\hline $\mathbf{T}_{5}$ & 5.39 & 5.35 & 5.37 & 26.23 & 18.89 & 22.32 \\
\hline $\mathbf{T}_{6}$ & 5.48 & 4.69 & 5.09 & 28.34 & 4.22 & 15.95 \\
\hline $\mathbf{T}_{7}$ & 5.73 & 5.50 & 5.62 & 34.19 & 22.22 & 28.02 \\
\hline $\mathbf{T}_{8}$ & 6.46 & 5.92 & 6.19 & 51.29 & 31.56 & 41.00 \\
\hline $\mathbf{T}_{9}$ & 6.67 & 6.23 & 6.45 & 56.21 & 38.44 & 46.92 \\
\hline $\mathbf{T}_{10}$ & 5.37 & 5.18 & 5.28 & 25.76 & 15.11 & 20.27 \\
\hline $\mathbf{T}_{11}$ & 5.67 & 5.53 & 5.60 & 32.79 & 22.89 & 27.56 \\
\hline$T_{12}$ & 5.92 & 5.56 & 5.74 & 38.64 & 23.56 & 30.75 \\
\hline $\mathbf{T}_{13}$ & 6.03 & 5.65 & 5.84 & 41.22 & 25.56 & 33.03 \\
\hline S. Em \pm & 0.077 & 0.13 & & & & \\
\hline C. D. at $5 \%$ & 0.225 & 0.386 & & & & \\
\hline
\end{tabular}

Table.4 Effect of varied levels of cogen ash on straw yield of paddy and Percentage increase in yield over control

\begin{tabular}{|c|c|c|c|c|c|c|}
\hline & \multicolumn{3}{|c|}{ Straw yield } & \multicolumn{3}{|c|}{$\begin{array}{c}\text { Percent Increase in straw } \\
\text { yield over control }\end{array}$} \\
\hline Treatments & Site-1 & Site-2 & Mean & Site-1 & Site -2 & Mean \\
\hline $\mathbf{T}_{1}$ & 4.95 & 5.10 & 5.03 & - & - & - \\
\hline $\mathbf{T}_{2}$ & 4.46 & 4.82 & 4.64 & -9.90 & -5.66 & -7.88 \\
\hline $\mathbf{T}_{3}$ & 5.04 & 5.63 & 5.34 & 1.82 & 10.71 & 6.26 \\
\hline $\mathbf{T}_{4}$ & 5.71 & 5.86 & 5.79 & 15.35 & 15.35 & 15.35 \\
\hline $\mathbf{T}_{5}$ & 6.16 & 6.16 & 6.16 & 24.44 & 21.41 & 22.83 \\
\hline$T_{6}$ & 6.08 & 5.26 & 5.67 & 22.83 & 3.23 & 12.93 \\
\hline $\mathbf{T}_{7}$ & 6.22 & 6.11 & 6.17 & 25.66 & 20.40 & 23.03 \\
\hline $\mathbf{T}_{8}$ & 6.66 & 6.26 & 6.46 & 34.55 & 23.43 & 28.89 \\
\hline $\mathbf{T}_{9}$ & 6.99 & 6.38 & 6.69 & 41.21 & 25.86 & 33.54 \\
\hline $\mathbf{T}_{10}$ & 5.83 & 5.83 & 5.83 & 17.78 & 14.75 & 16.16 \\
\hline $\mathbf{T}_{11}$ & 6.07 & 5.95 & 6.01 & 22.63 & 17.17 & 19.80 \\
\hline $\mathbf{T}_{12}$ & 6.26 & 6.09 & 6.18 & 26.46 & 20.00 & 23.23 \\
\hline $\mathbf{T}_{13}$ & 6.34 & 6.16 & 6.25 & 28.08 & 21.41 & 24.65 \\
\hline S. Em \pm & 0.099 & 0.141 & & & & \\
\hline C. D. at $5 \%$ & 0.29 & 0.41 & & & & \\
\hline
\end{tabular}


Table.5 Effect of varied levels of cogen ash on harvest index of paddy

\begin{tabular}{|c|c|c|c|}
\hline & \multicolumn{3}{|c|}{ Harvest index } \\
\hline Treatments & Site-1 & Site-2 & Mean \\
\hline $\mathbf{T}_{1}$ & 0.463 & 0.469 & 0.466 \\
\hline $\mathbf{T}_{2}$ & 0.468 & 0.465 & 0.467 \\
\hline $\mathbf{T}_{3}$ & 0.468 & 0.467 & 0.468 \\
\hline $\mathbf{T}_{4}$ & 0.469 & 0.470 & 0.470 \\
\hline $\mathbf{T}_{5}$ & 0.467 & 0.465 & 0.466 \\
\hline $\mathbf{T}_{6}$ & 0.474 & 0.471 & 0.473 \\
\hline $\mathbf{T}_{7}$ & 0.479 & 0.474 & 0.477 \\
\hline $\mathbf{T}_{8}$ & 0.492 & 0.486 & 0.489 \\
\hline $\mathbf{T}_{9}$ & 0.488 & 0.494 & 0.491 \\
\hline$T_{10}$ & 0.479 & 0.471 & 0.475 \\
\hline$T_{11}$ & 0.483 & 0.482 & 0.483 \\
\hline$T_{12}$ & 0.486 & 0.477 & 0.482 \\
\hline$T_{13}$ & 0.488 & 0.479 & 0.484 \\
\hline S. Em \pm & 0.0029 & 0.0014 & \\
\hline C. D. at 5\% & 0.00859 & 0.0042 & \\
\hline
\end{tabular}

The results are also similar to that of Jamil et al., (2007) who reported increased number of tillers $\mathrm{m}^{-2}$ as well as productive tillers $\mathrm{m}^{-}$ ${ }^{2}$,number of grains spike $^{-1}$ and 1000 grain weight in wheat and attributed to improvement in soil physical and chemical conditions and nutrients availability, which ultimately resulted in enhanced grain and straw yield and alleviation of deficiency of some of the essential nutrients and favorable effects of ash on soil physical conditions and microbial processes after the addition of bagasse ash to soil. The lower yields were obtained in the absence of FYM and with lower rates of cogen ash, this may be because of insufficient amount of nutrient supply and resulting in decreased activity of micro organisms to mineralize the organic matter and solubilize the unavailable or insoluble forms of nutrients.

Thus, the present study revealed that the paddy crop growth and yield was better due to recommended dose of NPK + recommended dose of FYM $+15 \mathrm{t} \mathrm{ha}^{-1}$ cogen ash compared to all the other treatments which clearly show that cogen ash can act as a source of plant nutrients.

Based on the results of the field experiment, it can be concluded that the paddy crop performed well when cogen ash was applied along with FYM and chemical fertilizers. The treatment $\mathrm{T}_{9}$ receiving recommended dose of fertilizers $+100 \%$ recommended dose of FYM $+15.0 \mathrm{t} \mathrm{ha}^{-1}$ cogen ash was found to be the best. The results of the study give useful information on usage of cogen ash for agricultural purpose. Application of recommended dose of fertilizers $+100 \%$ recommended dose of FYM $+15.0 \mathrm{t} \mathrm{ha}^{-1}$ cogen ash for paddy cultivation was found to be appropriate with respect to improved growth and yield of crop. Use of cogen ash in agriculture also helps in better waste management.

\section{Acknowledgement}

The author is thankful to College of Agricultural Sciences, G.K.V.K Bengaluru 
and Sri Chamundeshwari Sugars Ltd., Mandya for providing land, inputs, hospitality and other facilities required for conducting the above experiment.

\section{References}

Das, B.K., Choudhury, B.H. and das, K.N. 2013. Effect of integration of fly ash with fertilizers and FYM on nutrient availability, yield and nutrient uptake of rice in Inceptisols of Assam, India. Int. J. Adv. Res. Technol., 2(11): 2278-7763.

Dev, G. 1995. General meeting of the Indian Society of Soil Science at Ludiana. $J$. Indian. Soc. Sci., 43(4): 492-494.

Donald, C.M. and Humblin, T. 1976. The biological yield and HI of cereals as agronomic and plant breeding criteria. Adv. Agron., 28: 361-405.

Jamil, M., Qasim, M., Umar M. and Abdus Subhan. 2007. Impact of organic wastes (bagasse ash) on the yield of wheat (Triticum aestivum L.) in a calcareous soil. Int. J. Agri. Biol., 6: 3.

Milthrape Ans Ivins. 1966. The growth of cereals and grasses. Buttrworths, Londan, pp. 1345-1359.

Panse, V.G. and Sukhatme, P.U. 1967. Statistical methods for Agricultural Workers, ICAR, New Delhi.

Stosio, M. and Tomaszewicz, T. 1999. Impact of addition of coal ash from a power plant "Dolna Odra" on chemical properties of medium soil and yield of winter crops, Inzynieria Rolnicza, 5: 257-262.

Upadhayay, N.C., Sharma, R.C., Chaubey, I.P., Singh, D.B. and Singh, O.P. 2001. Impact of addition of sugarcane factory waste (maili) on crops productivity and soil fertility. J. Indian. Potato Assoc., 28: $36-37$.

\section{How to cite this article:}

Hamsa, N., C.A. Srinivasamurthy, S. Bhaskar and Varalakshmi, L.R. 2017. Utilization of Cogen Ash for Enhancing Growth and Yield of Paddy. Int.J.Curr.Microbiol.App.Sci. 6(5): 779785. doi: https://doi.org/10.20546/ijcmas.2017.605.088 